\title{
Survey on the Incidence of Post Flowering Stalk Rot of Maize in Telangana State during kharif - 2019
}

\author{
Ch. Mamatha*, B. Mallaiah, B. Vidyasagar and D. Bhadru \\ Department of Plant Pathology, PJTSAU, Rajendranagar, Hyderabad, India \\ *Corresponding author
}

Keywords

Fusarium verticillioides, Macrophomina phaseolina, Maize, Survey

\section{Article Info}

Accepted:

20 October 2020 Available Online: 10 November 2020

\begin{abstract}
A B S T R A C T
Maize (Zea mays L.) is one of the important cereal crops of the world and world's third leading cereal crop, after wheat and rice. Maize is affected by various biotic and abiotic stresses. Among the biotic stresses, fungal diseases are one of the major constraints in realizing the potential yields of this crop. So keeping in view the importance of maize diseases a survey was carried out during kharif-2019, in order to study the incidence of post flowering stalk rot in 13 villages of four major maize growing districts of Telangana state, viz. Karimnagar, Khammam, Warangal and Rangareddy. The incidence of wilt in different areas surveyed was ranged from 27.0 to 76.8 per cent. The maximum wilt incidence of 76.8 per cent was recorded in Thimmapur village of Karimnagar district, followed by 65.6 per cent at Gundlapalli village of Karimnagar ditrict. The minimum wilt incidence of 27.0 per cent was recorded at Narsimhapuram village of Khammam district. The pathogen was isolated from the infected stem showing typical vascular discolouration symptoms by tissue segment method on potato dextrose agar medium (PDA). The associated pathogens were isolated and identified on the basis of morphological characters, in which 12 isolates of $F$. verticillioides and 5 isolates of Macrophomina phaseolina were recovered. During study $F$. verticillioides pathogen alone noticed in more than $60 \%$ of samples collected.
\end{abstract}

\section{Introduction}

Maize (Zea mays L.) is one of the most versatile emerging crops having wider adaptability under varied agro-climatic conditions. It is cultivated in tropics, sub tropics and temperate regions under irrigated and rainfed conditions. Globally, maize is known as queen of cereals, because it has the highest genetic yield potential among the cereals. In most of the developing countries maize is consumed directly as food. Maize occupies an important place as a source of human food (26\%), animal feed (11\%), poultry feed $(48 \%)$, industrial products $(12 \%)$ and seed (3\%) in India. Maize is cultivated in an area of 9380.07thousand hectares with an annual production of 28752.8 thousand tons in India. In Telangana State, the crop is grown in almost all districts in an area of 630 thousand hectares with a production of 2555.64 thousand tonns and productivity of 4057Kg's/hectare (INDIANSTAT, 20172018). The other important maize growing 
states in India are Karnataka, Bihar, Rajastan, Maharashtra, Madhya Pradesh, Utter Pradesh, Andhra Pradesh, and Himachal Pradesh etc. Maize is affected by various biotic and abiotic stresses. Among the biotic stresses, fungal diseases are one of the major constraints in realizing the potential yields of this crop. Of the fungal diseases, post flowering stalk rots poses a major threat to the productivity of maize crop. Post flowering stalk rot is complex disease which occurs at post flowering stage of the crop in both kharif and Rabi season. In India, eight fungi and three bacteria were reported to cause stalk rots (Raju and Lal, 1976). Among all, Fusarium stalk rot (Fusarium verticillioides), Charcoal rot (Macrophomina phaseolina), Late wilt (Cephalosporium maydis) are more prevalent and destructive in India (Khokhar et al., 2014).Among the stalk rots, Fusarium stalk rot caused by $F$. verticillioides was first reported from USA by Pammel (1914) as a serious root and stalk disease. Later, Valleau (1920) reported that $F$. moniliforme was a primary cause of root and stalk rot of maize. In India, the disease was first reported from Mount Abu, Rajasthan (Arya and Jain, 1964) and prevalent in most of the maize growing areas of country where water stress occurs at the flowering stage of the crop.

The disease becomes apparent when crop enters senescence phase and severity increases during grain filling stage. The rotting extends from the infected roots to the stalk and causes premature drying, stalk breakage and ear dropping and thus resulting in reduction of maize yields (Colbert et al., 1987). The disease causes internal decay and discoloration of stalk tissues, directly reducing yield by blocking translocation of water and nutrients, thus resulting in death and lodging of the plant (Dodd, 1980).The fungus survives on crop residues in the soil or on the soil surface. Field observations revealed the difference in virulence with in
Fusarium verticillioides populations from different conventional maize growing areas indicating the emergence of new pathotypes. Hence, a survey was carried out in maize growing districts of state to determine the extent of disease severity and to trace the favourable conditions for disease occurance.

\section{Materials and Methods}

\section{Survey, collection and isolation of stalk rot infected samples}

An intensive roving survey was conducted during Kharif2019 to assess the wilt incidence in different maize growing areas of Telangana viz., Karimnagar (Jammikunta, Veenavanka, Huzurabad, Thimmapur, Gundlpalli), Khammam (Allipuram, Thanikella, Narsimhapura, Chintakani), Warangal (Arepally, Oglapur), Rangareddy (Rajendranagar) districts. At each location, the disease incidence recorded by counting the number of wilted plants out of total number of plants in a $4 \times 4 \mathrm{~m}$ area at all the four corners as well as centre of the field (Ramesha and Naik, 2017). Per cent disease incidence was calculated by using the formula

Per cent disease incidence $=\frac{\text { Number of plants affected }}{\text { Total number of plants observed }}$

Maize plants showing typical symptoms were collected from different locations and used for isolation of the pathogen (Plate. 1). These samples were first washed with tap water followed by sterile distilled water. Diseased portions with some healthy portion were cut into small bits of $3-5 \mathrm{~mm}$ size, surface sterilized by dipping them in sodium hypochlorite $(1 \%)$ solution for one minute and then 3-4 bits were transferred aseptically to petri plates containing potato dextrose agar (PDA) medium and were incubated at $25 \pm$ $1^{\circ} \mathrm{C}$ in an incubator (Aneja, 2003). 


\section{Single spore isolation}

The pathogen isolates from the infected tissue were further purified by single spore isolation method as described by Ho and Ko (1997). Spores were harvested from ten-day old culture with the help of an inoculation needle and suspended in one $\mathrm{ml}$ of sterile distilled water in a culture tube.

The suspension was vortexed for making a uniform suspension. Concentration of the spores was adjusted by addition of sterile distilled water. One $\mathrm{ml}$ of the spore suspension was transferred to petri plates containing $15 \mathrm{ml}$ of 2 per cent water agar medium.

The plates were incubated at $25 \pm 1^{\circ} \mathrm{C}$ for five hours. A well isolated single spore which initiated germination was located by observing the plate in an inverted position under a compound microscope.

Correspondingly a circle was marked around the spore over the plate and a circular disc of the medium containing the spore was picked up with the help of a sterile needle and transferred aseptically to petri plates containing PDA medium and incubated at 25 $\pm 1^{\circ} \mathrm{C}$ for further studies. Infected stalks collected were air dried under shade and kept for further studies.

\section{Results and Discussion}

A roving survey was conducted during Kharif, 2019 in different major maize growing areas of Telangana to assess the incidence of post flowering stalk rot and to isolate the associated pathogens. Survey was carried out in 13 villages of four major maize growing districts of Telangana and information on PDI, GPS, irrigated/ unirrigated and soil type was recorded (Table $1 \&$ Fig. 1). The incidence of wilt in different areas surveyed was ranged from 27.0 to 76.8 per cent. The maximum wilt incidence of 76.8 per cent was recorded in Thimmapur village of Karimnagar district, followed by 65.6 per cent at Gundlapalli village of Karimnagar district. The minimum wilt incidence of 27.0 per cent was recorded at Narsimhapuram village of Khammam district.

During survey it was observed that, wilt incidence was comparatively more prevalent in red soils with low soil moisture holding capacity and high soil temperature under rainfed conditions. Over all the survey reports revealed that PFSR incidence varied from field to field or location to location and it may be due to wide genetic diversity in corn hybrids, environmental conditions prevailed at a particular location, cropping pattern and management practices followed by the farmers.

Another important reason could be water stress at critical stages of crop growth especially during flowering because nutrient uptake and water stress leads to sever wilt incidence.

This results are in agreement with the Usharani and Menakasivam, (2019) who reported that increase or decrease trend in the incidence may be due to intense cultivation and continuous availability of host, pathogen and agronomic practices followed by the farmer. Rameshaand Krishna Naik, (2017) also found that maximum disease incidence was noticed in Chikkaballapura district because of favourable conditions prevailing during flowering compared to other districts.

Khokhar et al., (2014) also reported that the late sown crop suffered more because of heavy inoculum built up in the soil and moisture stress during flowering period and vice versa. 
Table.1 Survey on the incidence of PFSR of maize in different maize growing districts of Telangana duringkharif-2019

\begin{tabular}{|c|c|c|c|c|c|c|c|}
\hline S.No & District & Mandal & Place of collection & Latitude \& longitude & Soil type & Rainfed / Irrigated & *Wilt incidence $(\%)$ \\
\hline 1 & Warangal & Shyampet & Arepally & $\begin{array}{c}18^{0} 50.1024 ” \mathrm{~N} \\
79^{0} 37^{\prime} 20.892 \text { ”E }\end{array}$ & Red soils & Rainfed & $46.8(43.13)^{* *}$ \\
\hline 2 & Warangal & Atmakur & Oglapur & $\begin{array}{l}18^{0} 2{ }^{\prime} 59.244^{\prime \prime} \mathrm{N} \\
79^{0} 39^{\prime} 53.53 \text { ” }\end{array}$ & Red soils & Rainfed & $37.8(37.86)$ \\
\hline 3 & Rangareddy & Rajendranagar & Rajendranagar & $\begin{array}{c}17^{0} 19^{\prime} 33.15^{\prime \prime} \mathrm{N} \\
78^{0} 23^{\prime} 49.0416^{\prime \prime} \mathrm{E}\end{array}$ & Black soils & Irrigated & $49.2(44.52)$ \\
\hline 4 & Karimnagar & Jammikunta & Jammikunta & $\begin{array}{c}18^{0} 17^{\prime} 28.107^{\prime \prime} \mathrm{N} \\
79^{\circ} 27^{\prime} 50.74 \text { 'E }\end{array}$ & Red soils & Rainfed & $63.8(53.00)$ \\
\hline 5 & Karimnagar & veenavanka & Veenavanka & $\begin{array}{l}18^{0} 21^{\prime} 7.96 " \mathrm{~N} \\
79^{0} 24^{\prime} 46.17^{\prime \prime} \mathrm{E}\end{array}$ & Red soils & Rainfed & $59.6(50.52)$ \\
\hline 6 & Karimnagar & Huzurabad & Huzurabad & $\begin{array}{l}18^{0} 22^{\prime} 25.32^{\prime \prime} \mathrm{N} \\
79^{\circ} 50^{\prime} 46.33^{\prime \prime} \mathrm{E}\end{array}$ & Red soils & Irrigated & $56.8(48.89)$ \\
\hline 7 & Karimnagar & Thimmapur & Thimmapur & $\begin{array}{l}18^{0} 16^{\prime} 22^{\prime \prime} \mathrm{N} \\
79^{0} 14^{\prime} 40^{\prime \prime} \mathrm{E}\end{array}$ & Red soils & Rainfed & $76.8(60.65)$ \\
\hline 8 & Karimnagar & Medipalli & Gundlapalli & $\begin{array}{l}18^{0} 17^{\prime} 47^{\prime \prime} \mathrm{N} \\
79^{\circ} 63^{\prime} 3 \mathrm{E}\end{array}$ & Red soils & Irrigated & $65.6(54.07)$ \\
\hline 9 & Khammam & Konijerla & Allipuram & $\begin{array}{c}17^{0} 13^{\prime} 25^{\prime \prime} \mathrm{N} \\
30^{\circ} 9^{\prime} 11^{\prime \prime} \mathrm{E}\end{array}$ & Red soils & Rainfed & $28.4(32.14)$ \\
\hline 10 & Khammam & Konijerla & Thanikella & $\begin{array}{l}17^{0} 14^{\prime} 24.81^{\prime \prime} \mathrm{N} \\
20^{\circ} 15^{\prime} 22.87^{\prime \prime} \mathrm{E}\end{array}$ & Black soils & Irrigated & $32.0(34.42)$ \\
\hline 11 & Khammam & Thallada & Narsimhapuram & $\begin{array}{l}17^{0} 8^{\prime} 4^{\prime \prime} \mathrm{N} \\
80^{\circ} 11^{\prime} 5^{\prime \prime} \mathrm{E}\end{array}$ & Black soils & Irrigated & $27.0(31.27)$ \\
\hline 12 & Khammam & Chintakani & Chintakani & $\begin{array}{l}17^{0} 13,57.06 ” \mathrm{~N} \\
80^{0} 12,5.2524 " \mathrm{E}\end{array}$ & Black soils & Irrigated & $30.4(33.43)$ \\
\hline 13 & Khammam & Chintakani & Raghavapuram & $\begin{array}{c}17^{0} 88^{\prime}{ }^{\prime \prime} \mathrm{N} \\
80^{\circ} 11^{\prime} 54 " \mathrm{E}\end{array}$ & Black soils & Irrigated & $27.8(31.79)$ \\
\hline & \multicolumn{6}{|c|}{$\mathrm{CD}(\mathrm{P}=0.05)$} & 4.35 \\
\hline & \multicolumn{6}{|c|}{$\mathrm{SE}(\mathrm{m}) \pm$} & 1.52 \\
\hline & \multicolumn{6}{|c|}{ C. V. } & 7.38 \\
\hline
\end{tabular}


Table.2 Collection, isolation and identification of different pathogens associated with PFSR of maize in Telangana during kharif -2019

\begin{tabular}{|c|c|c|c|c|}
\hline $\begin{array}{c}\text { S. } \\
\text { No. }\end{array}$ & $\begin{array}{c}\text { Place of } \\
\text { collection }\end{array}$ & District & Name of the isolate & Code allotted \\
\hline $\mathbf{1}$ & Arepally & Warangal & Fusarium verticillioides & F-ISO-1 \\
\hline $\mathbf{2}$ & Oglapur & Warangal & Fusarium verticillioides & F-ISO-2 \\
\hline $\mathbf{3}$ & Rajendranagar & Rangareddy & $\begin{array}{c}\text { Fusarium verticillioides }+ \\
\text { Macrophomina phaseolina }\end{array}$ & $\begin{array}{c}\text { F-ISO-3+ } \\
\text { M-ISO-1 }\end{array}$ \\
\hline $\mathbf{4}$ & Jammikunta & Karimnagar & $\begin{array}{c}\text { Fusarium verticillioides }+ \\
\text { Macrophomina phaseolina }\end{array}$ & $\begin{array}{c}\text { F-ISO-4+ } \\
\text { M-ISO-2 }\end{array}$ \\
\hline $\mathbf{5}$ & Veenavanka & Karimnagar & Fusarium verticillioides & F-ISO-5 \\
\hline $\mathbf{6}$ & Huzurabad & Karimnagar & Fusarium verticillioides & F-ISO-6 \\
\hline $\mathbf{7}$ & Thimmapur & Karimnagar & $\begin{array}{c}\text { Fusarium verticillioides }+ \\
\text { Macrophomina phaseolina }\end{array}$ & $\begin{array}{c}\text { F-ISO-7 }+ \\
\text { M-ISO-3 }\end{array}$ \\
\hline $\mathbf{8}$ & Gundlapalli & Karimnagar & Fusarium verticillioides & F-ISO-8 \\
\hline $\mathbf{9}$ & Allipuram & Khammam & Fusarium verticillioides & F-ISO-9 \\
\hline $\mathbf{1 0}$ & Tanikella & Khammam & Fusarium verticillioides & F-ISO-10 \\
\hline $\mathbf{1 1}$ & Narasimhapuram & Khammam & Fusarium verticillioides & F-ISO-11 \\
\hline $\mathbf{1 2}$ & Chintakani & Khammam & $\begin{array}{l}\text { Fusarium verticillioides }+ \\
\text { Macrophomina phaseolina }\end{array}$ & $\begin{array}{c}\text { F-ISO-12+ } \\
\text { M-ISO-4 }\end{array}$ \\
\hline $\mathbf{1 3}$ & Raghavapuram & Khammam & Macrophomina phaseolina & M-ISO-5 \\
\hline
\end{tabular}

Fig.1 Survey on the incidence of post flowering stalk rot of maize in different maize growing areas of Telangana

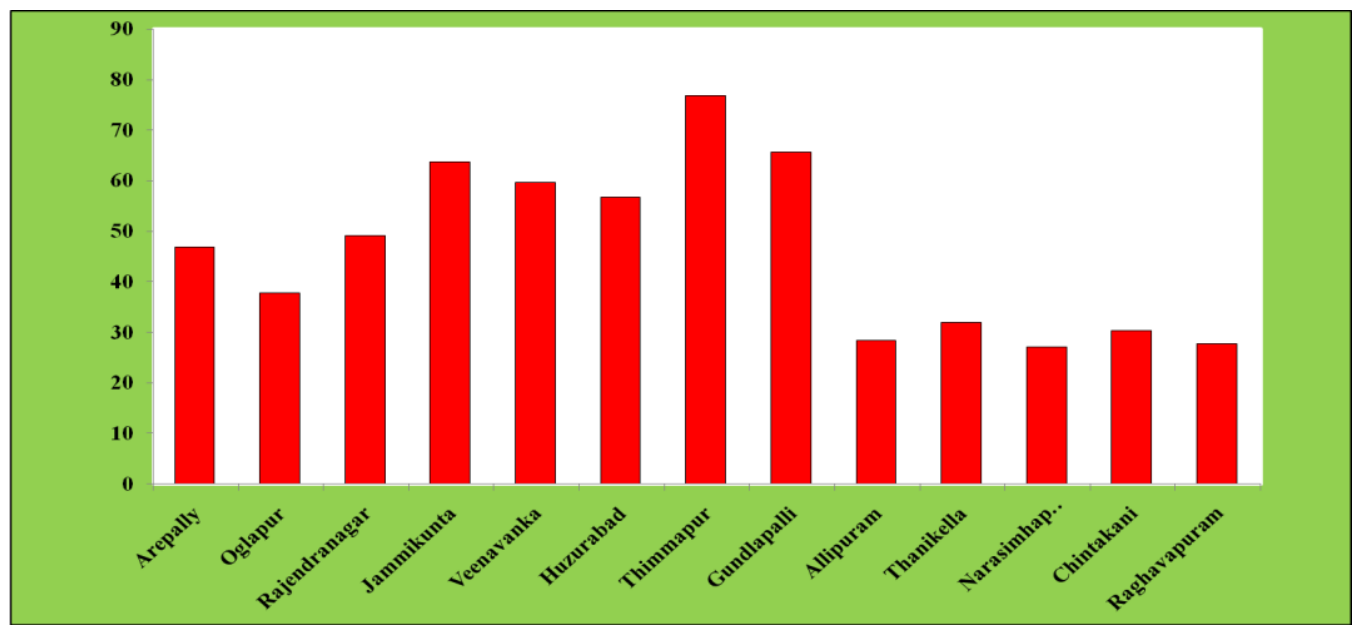


Plate.1 Symptoms of post flowering stalk rot of maize

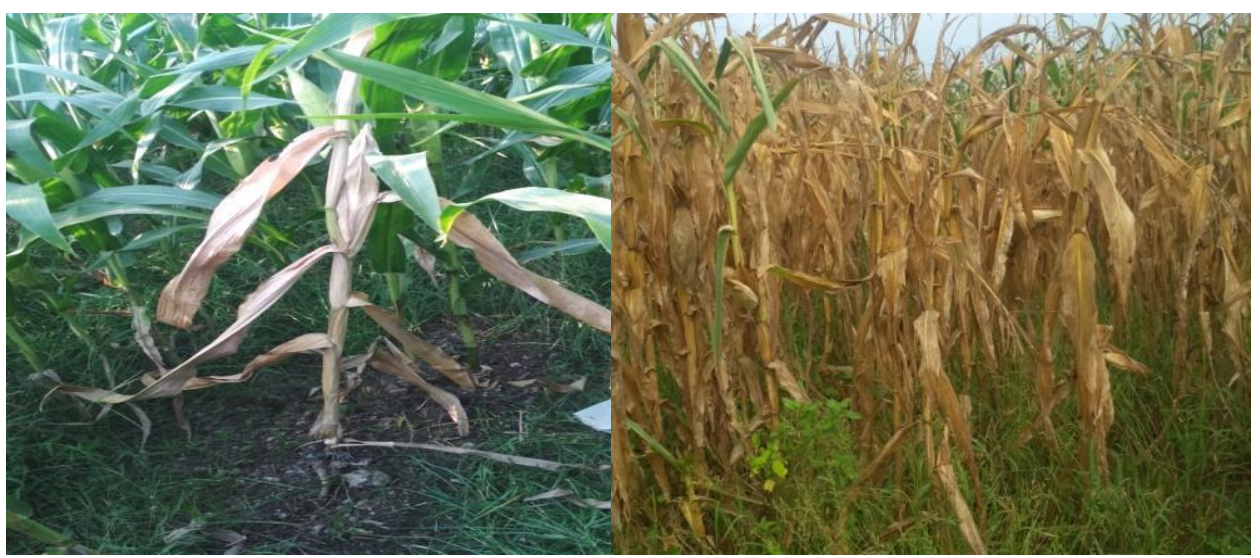

(a) Wilt infected stem in healthy field

(b) Complete wilt infected field

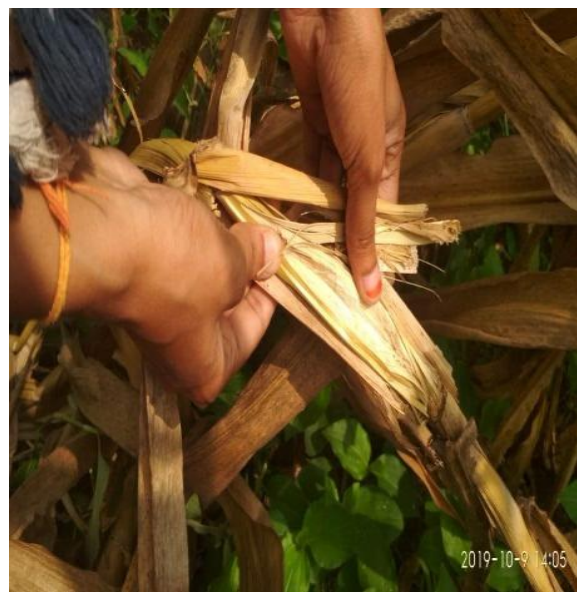

c) Brownish discolouration of vascular in wilt affected stem

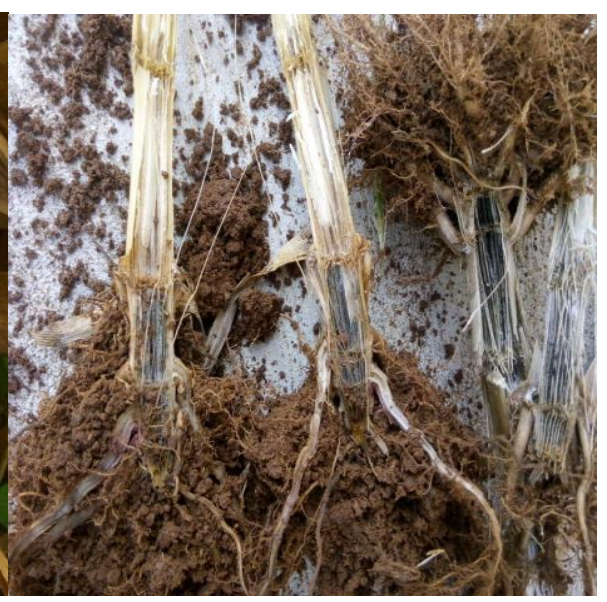

d) Black slerotial bodies inside the stem tissue

Plate.2 Morphological characters of Fusarium verticillioides (F-ISO-7)

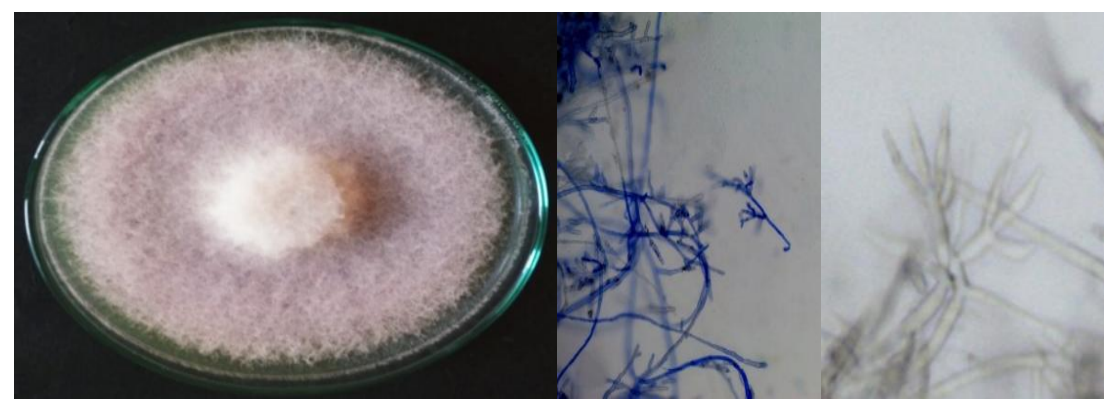

(a)

(b) 


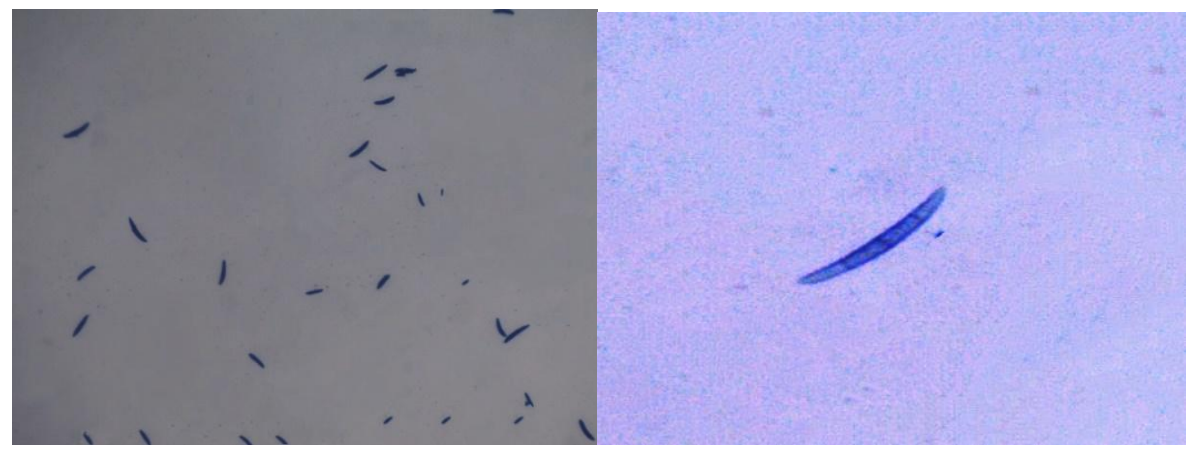

(c)

(d)

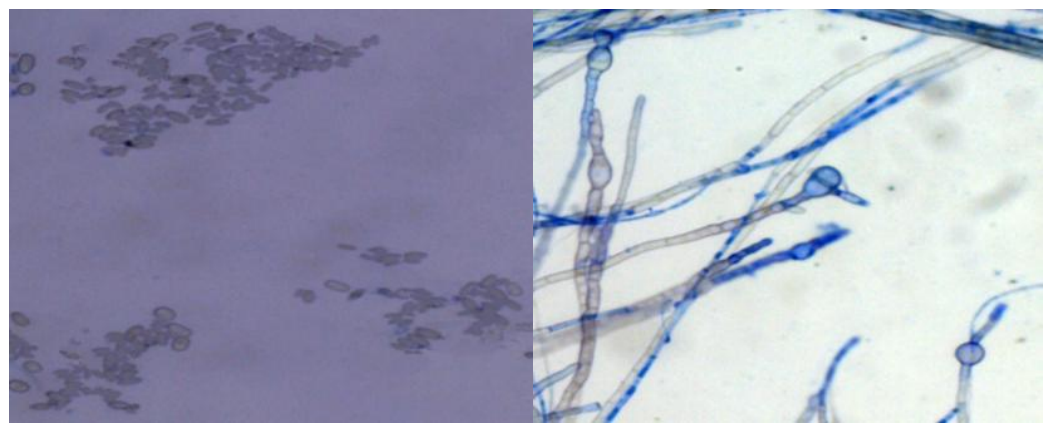

(e)

(f)

\section{Symptomology}

Typically two types of symptoms were observed in the field during the survey they are

\section{Type 1}

The stalk rot affected maize plants exhibited wilting appearance in batches at flowering. Showed symptoms of premature drying of lower leaves resulting in wilting or drying of the entire plant. The pith got dissolved, softened, stalk lost its strength and such stalks were straw colored and lodged. When we split open the stalks affected with stalk rot, light brown discoloration of the pith and some pink color pigmentation was observed. Pith region disintegrated but vascular bundles remain intact. Lodging was observed in severely affected plants. Infection of stalk was observed at $3^{\text {rd }}$ intermodal regions from the stem to soil interface. These symptoms are in accordance with reports of earlier workers
Borah et al., (2016) and Kenganal et al., (2017) who reported the softening and discoloration of the stalks near the first three internodes from the bottom are due to Fusarium verticillioides stalk rot of maize. The similar symptoms also described by Hooda et al., (2018) as a result of Fusarium stalk rot in maize.

\section{Type 2}

The Affected plant appeared with grayish streak on stalk. When stem cut open numerous minute black microsclerotia were observed on the shredded vascular bundles and on the inside of the stem, giving the interior parts of the stem a charred appearance. The crown region of the affected plant becomes dark in colour. Shredding of root bark and disintegration of root system were noticed. These symptoms are similar with reports of Smith, 1969 who confirmed that the disease is caused by soil borne fungus Macrophomina phaseolina (Tassi) Goid and 
also in accordance with the description of Hooda et al., (2018).

\section{Isolation and identification of the fungus}

The pathogens responsible for stalk rot of maize was isolated from affected plants showing typical symptoms on potato dextrose agar. Out of thirteen stalk rot samples used for the isolation of associated pathogens, from eight samples recovered only $F$. verticillioides and from four samples recovered both $F$. verticillioides and $M$. phaseolina indicating the complex nature of stalk rots, where as in one sample collected from Raghavapuram village with typical type two symptoms of charcoal rot yielded $M$. phaseolin. Dharanendra Swamy et al., (2019) isolated 132 Fusarium verticillioides isolates and 18 isolates of Macrophomina phaseolina from survey conducted on PFSR of maize in Karnataka.

The isolates were allotted with the code of FISO for Fusarium isolates and M-ISO for Macrophomina isolates. The isolates were named as F-ISO-1 and F-ISO-2 collected from Warangal; F-ISO-3 and M-ISO-1 collected from Ranga Reddy; F-ISO-4, FISO-5,F-ISO-6,F-ISO-7， F-ISO-8， M-ISO-2 and M-ISO-3 from karimnagar and F-ISO9,F-ISO-10,F-ISO-11, F-ISO-12, F-ISO-13, M-ISO-4 and M-ISO-5 from Khammam district (Table 2). Identification of these isolates was made based on morphological and cultural characters. The fungal colony of Fusarium isolates on PDA were initially white, floccose which turned purple to dark brown after 7 days of incubation at $28 \pm 2^{\circ} \mathrm{C}$ (Plate 2). Cultures developed pigmentation like pink, light purple, dark violet which varied with age.

Microconidia were hyaline, oval to club shaped with a flattened base and measured 5.12-6.41 X 2.04-3.18 (L×W). They were formed from monophialides and were found in long chains. Macroconidia observed were sickle shaped, hyaline with apical cell curved and tapered, and basal cell notched. They were typically 4-6 celled with 3-5 septa and measured 20.01-31.12x2.01-3.21 (L×W) (Plate 1). Thaware et al., (2017) also reported 8 isolates of Fusarium oxysporum f.sp. cicero with similar characteristics. Dharanendra Swamyetal. (2019) also confirmed these results in Karnataka. Based on the findings of cultural and morphological characters the pathogen was identified as $F$. verticillioides.

The mycelia growth was observed 24-48 h after inoculation on PDA medium in Macrophomina isolates. Within 6-7 days, the colonies became fluffy, carbonaceous, brown to black in colour covering the entire plate. With time numerous sclerotia developed throughout the colony. Mycelia were hyaline to grey or brown in colour, septate, branched, dendroid and frequently ran parallel to each other with right angled hyphae. Initially the hyphae was thin and became thicker with age. Sclerotia were black, varied from spherical to irregular in shape and measured 75 to 120 $\mathrm{mm}$ in diameter. Based on cultural and morphological characters the pathogen was identified as $M$. phaseolina. The morphology of the pathogen observed was in accordance with the description given for maize stalk rot pathogen $M$. phaseolinaby Abhay et al., (2020) and Iqbal et al., (2018).

\section{References}

Abhay, K.,Rishi, R.,Abhishek, R and Ramakrishnan, M. (2020). Morphological and molecular characterization of Macrophomina phaseolina isolated from three legume crops and evaluation of mungbean genotypes for resistance to dry root rot. Crop

Protection. https://doi.org/10.1016/j.cropro.2019.10 
4962.

Arya, H.C and Jain B.L. 1964.Fusarium seedling blight of maize in Rajasthan. Indian Phytopathology. 17: 51-57.

Borah, S.N., Deka, S and Sarma, H.K. 2016.First report of Fusarium verticillioides causing stalk rot of maize in assam, india. Plant Diseases. 100(3).

Colbert, T.R., Kang, M.S., Myers, $O$ and Zuber, M.S. 1987. General and specific combining ability estimates for pith cell death in stalk internodes of maize. Field Crop Research. 17: 155-162.

DharanendraSwamy, S., Mahadevakumar, S., Hemareddy, H.B., Amruthesh, K.N., Mamatha, S., Sridhara, G., Swapnil, R., Vasantha Kumar, T and Lakshmidevi, N. 2019. First report of Fusarium equiseti-the incitant of post flowering stalk rot of maize (Zea mays L.) in India.Crop Protection.DOI: https://doi.org/10.1016/j.cropro.2019.10 5035.

Dodd, J.L. 1980. Grain sinks size and predisposition of Zea mays to stalk rots. Plant Diseases. 64: 553-537.

Hooda, K. S., Bagaria, P. K.., Khokhar, M., Kaur, H and Rakshit, S. (2018). Mass screening techniques for resistance to maize diseases. ICAR-Indian Institute of Maize Research, PAU Campus, Ludhiana- 141004. Page 68-70.

Ho, W.C and Ko, W.H. 1997. A simple method for obtaining single spore isolation of fungi.Botanical Bulletin of Academia Sionica. 38: 41-44.

Iqbal, M., Usman Ghazanfar, $\mathbf{M}$ and Imran Hamid, M. (2018).Cultural and morphological variability of Macrophomina phaseolina (Tassi) Goid causing charcoal rot of sunflower in Sargodha Pakistan. International Journal of Biosciences. 13(5): 371-377. DOI:

http://dx.doi.org/10.12692/ijb/13.5.371377.
INDIASTAT.2016-2017. http://www.indiastat.com/agriculture/2/s tats.aspx.

Kamari, B and Patra, C. 2018. Evaluation of antifungal potency of natural products against stem and root rot of sesame. Journal of Pharmacognosy and Phytochemistry. 7(6): 156-158.

Kenganal, M., Patil, M.B and Nimbaragi, Y. 2017. Management of stalk rot of maize caused by Fusarium moniliforme (Sheldon). International Journal of Current Microbiology and Applied Sciences. 6(9): 3546-3552.

Khokar, M.K. 2014. Epidemiology and management of post flowering stalk rot of maize caused by Fusarium verticillioides (sacc.). Ph. D. Thesis submitted to MaharanaPratap University of Agriculture and Technology, Udaipur, Rajasthan (India) in partial fulfillment of the requirements for the award of the degree of $\mathrm{Ph}$. D. in Agriculture. 173.

Khokhar, M.K., Sharma, S.S and Gupta, R. 2014. Integrated management of post flowering stalk rot of maize caused by Fusarium verticillioides. Indian Phytopathology. 67(3): 228-233.

Khokar, M., Hooda, K.S., Sharma, S.S and Roat, B.L. 2015.Morphological and molecular characterization of Fusarium spp. causing post flowering stalk rot of maize. International Journal of Plant Research. 28(1): 113-121.

Olowe, O.M., Sobowale, A.A., Olawuyi, O.J and Odebode, A.C. 2018.Variation in pathogenicity of Fusarium verticillioides and resistance of maize genotypes to Fusarium ear rot.Archives of Phytopathology and Plant Protection.51(17): 939-950.

Pammel, L.H. 1914. Serious root and stalk diseases of corn. IOWA Agriculturist.15: 156-158.

Raju, C.A and Lal, S. 1976. Relationship of 
Cephalosporium acremonium and Fusarium moniliforme with stalk rot of maize. Indian Phytopathology. 3: 227231.

Smith, W. H. (1969). Comparison of mycelial and sclerotial inoculum of Macrophomina phaseolina in the mortality of pine seedlings under varying soil conditions. Phytopathology.59: 379-382.

Sobawale, A.A., Cardwell, K.F., Odebode, A.C., Bandyopadhyay, R and Jonatan, S.G. 2005. Growth inhibition of Fusarium verticillioides (sacc.) Nirenberg by isolates of Trichoderma pseudokoningii strains from maize plant parts and its rhizosphere. Journal of plant protection and research. 45(4): 249-266.
Thaware, D.S., Kohire, O.D and Gholve, V.M. 2017. Cultural, morphological and molecular variability of Fusarium oxysporum f. sp. ciceri isolates by RAPD method. International Journal of Current Microbiology and Applied Sciences. 6(4): 2721-2734.

Usharani, S and Menakasivam, S. 2009. Biocontrol of crossandra wilt incited by Fusarium solani with rhizosphere mycoflora. Plant disease research. 24(2): 146-147.

Valleau, W.D. 1920. Seed corn infection with Fusarium moniliforme and its relation to the root and stalk rots. Kentucky Agricultural Experiment Station. 226: 51.

\section{How to cite this article:}

Mamatha, Ch., B. Mallaiah, B. Vidyasagar and Bhadru, D. 2020. Survey on the Incidence of Post Flowering Stalk Rot of Maize in Telangana State during kharif - 2019. Int.J.Curr.Microbiol.App.Sci. 9(11): 2745-2754. doi: https://doi.org/10.20546/ijcmas.2020.911.333 